\author{
Izabela Kapera \\ ORCID 0000-0003-1691-5275 \\ Krakowska Akademia im. A. Frycza Modrzewskiego \\ Wydział Prawa, Administracji i Stosunków Międzynarodowych \\ lowczowska@poczta.onet.pl
}

\title{
SUSTAINABLE DEVELOPMENT IN THE HOTEL INDUSTRY: BETWEEN THEORY AND PRACTICE IN POLAND'
}

\begin{abstract}
The aim of the paper is to discuss the current state, implementation capabilities and barriers to the implementation of sustainable development principles in the hotel industry in Poland. The paper examines the issue on the basis of the evolution and implementation of sustainable development principles at hotels. Best practices are analyzed in terms of the introduction of these principles and practical problems in the implementation process are also scrutinized.
\end{abstract}

Keywords: tourism, sustainable development, hotel industry.

\section{INTRODUCTION}

Growing interest in the principles of sustainable development, and the resulting pressure from media, government and consumer sources to increasing activity levels in this area, forces many companies to increasingly implement policies that are more friendly towards the environment. The practice of sustainable development in relation to business operations is the ability to maintain a business in the long term thanks to profits, environmental effectiveness, and social engagement that together forge a forward-looking path to development. Sustainable development in the hotel and restaurant industry examines innovative ways of managing continuously growing electricity and water costs as well as the moral, ethical, social and political arguments behind these practices (SLOAN, LEGRAND \& CHEN 2009). Sustainable development requires a holistic approach to business that covers three key areas - the environment, social issues, and economics.

While it may be effectively argued that the hotel industry is increasingly taking responsibility for the natural environment (VON RHEEDE \& BLOMME 2012), and that some practices linked with sustainable development may be considered virtually universal at this point in time, their presence at a given hotel facility remains less important to hotel guests than both price and convenience (BRUNS-SMITH et al. 2015). The hotel industry's pursuit of sustainable development is the result of several factors. First, the number of individuals seeking accommodation that provides a greater degree of respect for the environment is growing continuously (FERMANI, CRESPI \& STARA 2016). The tourist services market is experiencing the appearance of a new type of consumer who is able to pay more for ecologically-oriented products and services (NIEZGODA 2010).

Research has shown that more than $60 \%$ of hotel guests believe that hotels should pursue certain proecological steps associated with environmental protection, reduction of operating costs and a variety of promotional effects and a positive impact on a hotel's public image (KAPERA \& WSZENDYBYE-SKULSKA 2017). According to M. HENDEL (2016), the relationship between the environment and society will become clearer to consumers in the future, and pro-ecological steps may become a source of competitive advantage, as some consumers may prefer to purchase more proecological products (HENDEL 2016). Increasing consumer requirements and changes in purchasing behavior as well as the emergence of new consumption models may prompt the tourism industry to adapt (HENDEL \& ŻEMŁA 2016). Current and future managers of hotels will want to know how sustainable systems of management can become integrated into hotel industry practices in order to maintain or even improve financial performance (SLOAN, LEGRAND \& CHEN 2009). However, it is difficult not to note certain paradoxes that are readily observable upon a closer inspection of 
this issue. The hotel industry creates conditions for access to tourist attractions. Hence, there is pressure to locate hotels in naturally attractive areas, which is contradictory to the idea of sustainable development. It sometimes happens that the postulate of reducing the pressure of tourism on the most valuable natural areas is in conflict with tourism development plans assuming for example the construction of large accommodation facilities (Pogranicze polsko-słowackie. Dostępność transportowa a turystyka 2012). At the same time, the industry is increasingly willing to implement many sustainable development practices, while on the other hand, it is difficult not to notice a certain type of consumerism that in many ways represent the antithesis of sustainable development (JONES, HILLIER \& COMFORT 2016). Several major hotel corporations now emphasize their involvement with the principles of sustainable development in terms of how it fits into their basic business strategy. This is occurring at a time of immense growth that includes demand for environmental resources.

In the light of these contradictions, the purpose of the study is to discuss the current state of affairs, opportunities and barriers to the implementation of the principles of sustainable development in the hotel industry in Poland. The implementation of the project was supported by the literature, in which an analysis of Polish and foreign source materials, including reports, expert opinions and strategies related to sustainable development, was carried out. The study showed that there is little evidence in the national literature of the concept of sustainable development in relation to hotel companies. E. SZYMAŃSKA (2014) draws attention to this cognitive gap, at the same time proposing the need for closer cooperation between entrepreneurs and the universities that educate and conduct research in the discussed area (SZYMAŃSKA 2014).

\section{SUSTAINABLE DEVELOPMENT AND THE HOTEL INDUSTRY}

The term 'sustainable development' is increasingly often used in many different areas of academic research and business. While this concept is now widely known, it continues to encounter difficulties in the way it is defined, measured, and used in practice. According to L. Butowski, the research literature provides a descriptive approach to sustainable development in the area of tourism and a variety of research directions that have resulted in ambiguous definitions (BUTOWSKI 2013). Yet, M. KAZIMIERCZAK (2010) notes that "the idea of sustainable development when confronted with the reality of a world in the stage of late capitalism make's one aware of the strong discrepancy between the slogans of sustainable development and actual practice, which is also true of tourism at local and global levels." M. MIKA (2015) draws a similar conclusion, noting that attempts to utilize in practice the idea of sustainable tourism exhibit a substantial mismatch between the basic assumptions of sustainable development and the reality of tourism industry development and various characteristics of social and economic development in general. The problem is mostly driven by the fact that a requirement of maintaining environmental, social, and economic sustainability in the tourism market presents a barrier to its functioning due to the limited willingness of tourists to curb their behavior and make personal sacrifices or give up some of their decision-making power when travelling (MIKA 2015). A state close to that of sustainable development occurs when active participants in a system show a desire to place limitations on themselves (KOWALCZYK 2010). At many major hotel chains, a sustainable development strategy is an element of broader company policy. However, the question remains: do international hotel chains, characterized by standardized offerings including buildings, rooms, services, and restaurant menus, really create any linkages with local cultures or products? J. KRONENBERG (2011) investigated this issue using the example of a hotel in the town of Tomaszowice. Even in the face of criticism, the idea of sustainable development is slowly gaining widespread acceptance, and sometimes even seemingly random grassroots initiatives evolve into complex and comprehensive business strategies that factor in the needs of both customers and stakeholders.

Sustainable development remains linked with the concept of social responsibility in business. It is important to note that the two approaches are not identical. According to A. PRZYBYLSKA (2012), social responsibility in business is first and foremost the management strategy of a company designed to contribute most to the sustainable development of society, which is in practice characterized by "well-thought out efforts to help the environment, specific staffing policies, and supporting the local community and local suppliers by purchasing local goods" (PRZYBYLSKA 2012). The role of social responsibility has been noticed by both business and non-business entities. The International Standardization Organization (ISO) published the ISO 26000 Guidance on Social Responsibility in 2010. The document applies to all organizations (including public, private and non-profit), and provides guidelines on social responsibility defined as "the responsibility of an organization for its decisions and their effects on society and the environment, which is manifested via transparent and ethical actions that:

- contribute to sustainable development including the health and welfare of society by factoring in the expectations of stakeholders or individuals and groups 
interested in the decisions and actions of a given organization,

- follow existing laws and international norms of organizational behavior,

- integrate well with ongoing efforts of organizations and their impacts on ambient environments" (ISO 26000 Guidance on Social Responsibility 2010).

The aim of social responsibility is to support sustainable development (PN-ISO 2600, 2012). Yet it would be futile to search for a single definition of sustainable development that would be widely accepted. In addition, the current view of sustainable development is evolving due to changes in a broader context. Given the nature of this study and the need to base it on a formal definition, sustainable development is a form of social and economic development that involves the integration of political, social, and economic efforts along with the maintenance of an environmental balance in order to assure the permanence of environmental processes that serve to meet the basic needs of current and future generations (Environmental Protection Law, 2001).

An increasing number of companies are treating sustainable development as a form of competitive advantage. This trend is due to a number of different factors including the need to adapt to legal regulations, fears of rising costs and shortages of natural resources, increasing awareness on the part of the general public and shareholders of the issue of social awareness, increasing interest on the part of the media, attempts to differentiate oneself from the competition, and the desire to help improve the reputation of one's company (JONES, HILLIER \& COMFORT 2016). Studies on sustainable development in the hotel industry are also increasing in number. The current number remains small, but they are important in the broader context of research on sustainable tourism in terms of their significance in the social, ecological, and economic systems investigated (MELISSEN 2013). P. JONES, D. HiLLIER \& D. COMFORT (2016) delve into a number of themes examined in the world literature on sustainable development in the hotel industry. These include the design of 'green' hotels, minimalization of energy consumption, the role of technological progress in the attainment of sustainable development, sustainable tourism, the marketing of sustainable development, consumer views, and prospects in terms of the management of human resources (JONES, HILLIER, COMFORT 2016).

The basic problem is the way sustainable development is defined in the hotel and restaurant sector. While the academic approach to this definition is rooted in the needs of modern hotel guests, hotel owners, and stakeholders as well as the need to meet their future needs, the approach taken by the hotel industry in general is expressed in terms of key business goals and strategies. Hence, in this context, leading global hotel chains create sustainable development programs largely and sometimes solely based upon their own business goals. This approach assumes an emphasis on efficiency in both environmental and social areas and does not focus on the maintenance of natural ecosystems or scarce natural resources (JONES, HILLIER \& COMFORT 2016). Most large players in the hotel industry publicly engage in strategic corporate actions and programs of sustainable development. Many choose to inform the general public of their social responsibility and achievements in this area and in the area of caring for the natural environment. The problem appears with smaller hotels that are not linked with any international system or hotel chain. In this case, sustainability-related actions are less common or are not described in terms of programs of sustainable development in cases where they do occur. Research has shown that there exists a problem with the engagement of internal stakeholders in the sustainability-related activity of smaller hotels (JONES, HILLIER \& COMFORT 2016). This issue is related to educational efforts in the area of sustainable development. Despite significant popular interest in this area, sustainable development is rarely included in academic curricula in the field of tourism, and especially hotel management, in Poland. A study was conducted in Poland in 2012 whose goal was to prepare an expert analysis of sustainable development education in Poland. The final report states that there does not exist a unified and formalized collaboration network that would connect educational and business entities potentially providing jobs for university graduates as well as connecting educational institutions themselves (Expert analysis of sustainable development education in Poland - Final Report 2012).

\section{THE HOTEL INDUSTRY IN POLAND IN THE CONTEXT OF SUSTAINABLE DEVELOPMENT}

In Poland the concept of sustainable development is included in Article 5 of the Constitution of the Republic of Poland. In addition, it is also part of a number of other Polish laws and strategic documents. The country's Strategy for Responsible Development up to 2020 with extensions up to 2030 is Poland's main development strategy document. Its fundamental purpose is to "help create conditions that would facilitate increasing incomes for the residents of Poland along with greater social, economic, environmental, and geographic cohesion" (Strategy for... 2017). Tourism in Poland is aided by the adoption of a Tourism Development Program up to 2020 as well as a Marketing Strategy for Poland for the Tourism 
Sector for the Period 2012-2020. The programs were approved by the Council of Ministers in 2015 and assume assistance in order to help increase the competitiveness and innovativeness of the tourism industry by supporting businesses, various organizations, and initiatives put forth by the tourism industry, while respecting the principles of sustainable development (Tourism development... 2015). Operational goals identified in the state-managed tourism program are specifically linked with the principles of sustainable development.

These efforts emphasize the significance of innovativeness and note the need for higher levels of social engagement and business entrepreneurship in the tourism sector as well as the need for more education or training of personnel working in the sector. The last operational goal raises the issue of the development and modernization of physical spaces for the purpose of growth in the tourism sector and the development of a better tourist-oriented infrastructure while following the principles of sustainable development and environmental protection laws (Tourism development... 2015). The Marketing Strategy does mention global trends in tourism including a direct reference to the idea of sustainable development, but lacks a comprehensive approach to the implementation of the principles of sustainable development. Existing tourism-related laws in Poland do not follow global trends in sustainable tourism either. At the same time, the tourism industry does not feel the need to follow the principles of sustainable development in the absence of laws that would mandate their implementation. In addition, a new norm known as the Polish Norm PN-ISO 26000: 2012 was formulated in 2012 in order to provide guidelines on social responsibility in the context of sustainable development. This norm is a translation of an English-language version of International Norm ISO 26000: 2010, which was formulated in order to help organizations pursue activities designed to facilitate sustainable development (PN-ISO 26000: 2012, 2012).

The new norm may be helpful in actions taken by hotels pursuing sustainable development goals. The number of such hotels is gradually increasing, which also increases the likelihood of greater implementation. A total of 10,681 'lodging facilities' were registered in Poland in 2017 (Tourism in 2017 2018). Hotels in Poland tend to be owned locally, as opposed to major hotel chains. Most are operated directly by their owners and only $6 \%$ operate under an international brand designation (Poland Market Insights Annual Report 2016). Hotels operated by international systems and hotel chains are often obligated to perform activities in line with the principles of sustainable development, which are built into the business strategies of various global brands. The main players in the Polish hotel market that are part of larger hotel systems most often develop their own strategies of sustainable growth along with ways to monitor their effects on the basis of their own benchmarks. The work of M. SZTORC (2017) has shown that the implementation of sustainable development strategies at hotel chains is treated as a key element of their promotional strategy (SZTORC 2017). Independent hotels have a different formula for sustainable development: hospitality, friendliness, and frequent contact with guests (DOMINIK 2017). Other studies show that this formula reflects aspects of local culture and the natural environment which works well in the local hotel market (SALA 2009).

\section{PURSUIT OF SUSTAINABLE DEVELOPMENT AT HOTELS}

Hotel management companies should engage in proecological and pro-social activity designed to address the well-being of their employees and guests (BORKOWSKA-NISZCZOTA 2015). Hotels today are increasingly attempting to control costs by limiting water and power usage, triggered also by consumer interest in business impact on the natural environment. Despite years of work to reduce water and power use by hotels, the level of usage today remains significant. However, the effort has not been in vain - both cost savings and protection of the natural environment are goals worth pursuing. Sustainable development requires collaboration with the local community. On the one hand, this means that certain activities may be pursued together with the local community. On the other hand, it means that businesses need to inform the local community about what they are doing. Engagement with the local community should be continuous and should be characterized by an attempt to solve real social problems, the development of partnerships, promotion of culture, educational work, and 'investment' in social issues (BORKOWSKA-NISZCZOTA 2015).

E. MAZUR-WIERZBICKA (2018) analyzed work related to corporate social responsibility at a number of hotels in Poland and found that this sort of work does occur at the studied groups of hotels. Some efforts target employees in the form of programs related to healthcare, safety, training, mobility-related policies, career development, proactive staffing policies, and advanced motivational work (MAZUR-WIERZBICKA 2018). Some efforts target the local community in the form of initiatives to respect social and ethical principles at work and outside of work, charitable work, assistance to children's homes, schools, preschools, organizations for disabled members of the community, protection of 
Table 1. Examples of pro-ecological and pro-social work pursued by hotel-type organizations

\begin{tabular}{|c|c|}
\hline Type of activity & Description \\
\hline \multicolumn{2}{|r|}{ Facility design and construction stage } \\
\hline Location of facility & $\begin{array}{l}\text { Choice of facility location affects subsequent activities taken in the area of pro-ecological and } \\
\text { pro-social endeavors. Facility location depends on facility type and other factors. Urban } \\
\text { locations make it possible to utilize existing power and water infrastructure, and this is the } \\
\text { case with many business hotels. Hotels located outside major cities have the option of using } \\
\text { alternative sources of both water and electrical energy, as is the case with many health spa } \\
\text { and recreational-type hotels. }\end{array}$ \\
\hline $\begin{array}{l}\text { Location of facility and the scheme } \\
\text { of rooms }\end{array}$ & $\begin{array}{l}\text { Hotel rooms need full access to sunlight and should face south. Kitchens and warehousing } \\
\text { areas should face north. }\end{array}$ \\
\hline $\begin{array}{l}\text { Utilization of ecological construction } \\
\text { technologies and construction } \\
\text { materials }\end{array}$ & $\begin{array}{l}\text { Technologies, materials, insulation, sources of energy including alternative sources, saving } \\
\text { water, wastewater generation. }\end{array}$ \\
\hline $\begin{array}{l}\text { Installation of ecological elements } \\
\text { of hotel interiors including reused } \\
\text { elements }\end{array}$ & $\begin{array}{l}\text { Furniture, floor coverings, bathroom appliances and equipment, entertainment equipment } \\
\text { such as television sets. }\end{array}$ \\
\hline $\begin{array}{l}\text { Greenery as an element of pro- } \\
\text { environmental policy }\end{array}$ & $\begin{array}{l}\text { Design of green areas outside the hotel facility and allocation of potted plants inside the } \\
\text { facility. }\end{array}$ \\
\hline Pro-social efforts & Employment of a local labor force and products made locally. \\
\hline \multicolumn{2}{|r|}{ Everyday hotel operations } \\
\hline Water and sewage & $\begin{array}{l}\text { Reduced water usage via the use of faucet aerators, use of stored rainwater, requests to guests } \\
\text { to conserve water. }\end{array}$ \\
\hline Electrical energy and heat & $\begin{array}{l}\text { Energy savings via the use of electronic access systems, devices with proper energy certi- } \\
\text { ficates, power-conserving lightbulbs, alternative heating sources. }\end{array}$ \\
\hline Household waste & $\begin{array}{l}\text { Waste reduction by using products sold in large packages, use of multiple-use materials, } \\
\text { encouraging and motivating employees and guests to sort waste products, use of trash } \\
\text { containers that enable the segregation of garbage, hotel decorations (especially those that } \\
\text { reflect the nature of the region). }\end{array}$ \\
\hline Ecological certificates and standards & E.g. Green Key, Ecolabel, Green Globe, Trevelife, appropriate ISO standards. \\
\hline Hotel services & $\begin{array}{l}\text { Hotel room strategy: ask guests to make an effort to save energy, water, and segregate trash. } \\
\text { Hotel restaurant strategy: green menu, local products. Other services: ecological conferences, } \\
\text { meetings and celebrations and follow the principles of sustainable growth. }\end{array}$ \\
\hline Employee-related efforts & $\begin{array}{l}\text { Counteracting discrimination, protection of employee rights, and dialogue with employees. } \\
\text { Concern for employees via healthcare packages, fitness packages, creative training options. } \\
\text { Efforts to hire employees with the following key concerns in mind: gender equality, profes- } \\
\text { sional development, employee mobility, efforts to counteract age discrimination. Employee } \\
\text { training and designation of employees to implement the principles of sustainable growth and } \\
\text { formulate pro-environmental policies as well as monitor the outcomes of all above efforts. }\end{array}$ \\
\hline Customer-related efforts & $\begin{array}{l}\text { Use of honest practices in marketing, employment contracts, other contracts, education, hotel } \\
\text { security, and service quality. Informing hotel guests about efforts in the area of sustainable } \\
\text { development. The hotel facility should feature signs and pictograms that show guests how } \\
\text { to save water, electricity, and heat. Show appreciation for guests who do generate savings } \\
\text { and reward this type of guest behavior. }\end{array}$ \\
\hline Obligations to suppliers & $\begin{array}{l}\text { Honesty-based relationships with partner companies/suppliers. Informing and promising } \\
\text { partners that certain practices are in fact being employed. Giving consideration to sustain- } \\
\text { ability issues when selecting business partners. Collaboration with partners on issues } \\
\text { associated with sustainable development. }\end{array}$ \\
\hline Obligations to the local community & $\begin{array}{l}\text { Attempts at social dialogue. Purchasing products from local producers, supporting non- } \\
\text { governmental organizations, focusing on local organizations, initiatives related to children's } \\
\text { homes, schools, and assistance to children from families experiencing difficulties. }\end{array}$ \\
\hline
\end{tabular}

Source: author. 
children against sexual abuse, and provision of accommodation friendly towards families. The strategy also includes a code of ethics in relation to suppliers, promotion of products produced by ecological farms and sustainable agriculture as well as their suppliers (MAZUR-WIERZBICKA 2018). The strategy in relation to customers includes honest marketing, protection of the health of customers, the safety of customers, promotion of sustainable consumption, proper care of customers, protection of customers' personal information, and protection of customers' property (ed. CITKOWSKI 2010). It shows that activity in the field of sustainable development can be started at the hotel design stage (location of the facility, location of rooms), and then undertaken in the context of tangible components of the hotel service (e.g. equipment) and its intangible dimension (e.g. staff training).

Hotel operators aware of the many potential economic benefits of implementing the principles of sustainable development promote their participation in sustainable programs and seek out various ecological certificates which may certify some hotel functions or all functions. In addition to items listed in Table 1, the Polish Green Building Council has a database of certified buildings via the BREEM system - Building Research Establishment Environmental Assessment Method - which serves to gauge the impact of buildings on the natural environment and the quality of the buildings themselves. The database includes the following hotels: Andel's Hotel - Kraków, Ibis - Gdańsk Old City, Mercure Hotel - Kraków Centrum, Hilton Garden Inn - Kraków (Konopnickiej St), InterContinental - Warsaw, Radisson Blu Hotel - Kraków. LEED is an internationally recognized system of certification that helps owners and building managers to implement solutions in the area of the design, construction, utilization, and maintenance of buildings in a pro-ecological manner. The following hotels in Poland hold a LEED (Leadership in Energy and Environ-mental Design) certification: Gdynia Waterfront - Courtyard Marriott, Hampton by Hilton - Warsaw City Centre, The Westin - Warsaw, Holiday Inn - Warsaw City Centre (https:/ / plgbc.org.pl/baza-budynkow-certyfiko wanych/).

\section{BARRIERS TO THE IMPLEMENTATION OF SUSTAINABLE DEVELOPMENT PRINCIPLES ON HOTEL PRACTICE}

Barriers associated with the implementation of the principles of sustainable development are largely linked with barriers to implementation in the field of tourism in general. The lack of a single definition of sustainable development and means to measure its degree of implementation serve as weak spots in the system that also affects the hotel industry. This is in addition to the unwillingness of both tourists and hotel owners to place limitations upon themselves in the area of sustainable growth. According to J. BOHDANOWICZ \& P. BOHDANOWICZ (2004), ecological pressure on tourism is needed both on the supply side and the demand side (BOHDANOWICZ \& BOHDANOWICZ 2004). While hotel owners are starting to follow the path of sustainable development, it is difficult to encourage hotel guests to place limitations upon themselves. Hotel guests suspect that lower costs associated with power, water, and sewage reductions are largely incurred at their expense and the resulting profits are funnelled to hotel owners. In this context, it is necessary to inform guests about the benefits to the natural environment, and create a system of incentives that would prompt guests to place environmentally desirable limitations upon themselves.

Something as simple as posting a request in a hotel room for guests to reuse a towel may signal to a guest that a given hotel is friendly towards the natural environment, although its effectiveness may be limited. Some hotels already use incentive systems that yield measurable results, although most hotels propose a similar array of activities related to sustainable development. In addition, the social aspect of sustainable development in the hotel and restaurant business tends to be much less advanced than that related to the natural environment. The issue of informing the general public about sustainable practices is yet another problem area. While large international systems and hotel chains have already created information mechanisms that generate image-related benefits, smaller hotels often are not skilled in the art of informing the public about their sustainable development efforts. Some pro-social and pro-ecological smaller hotels simply do not know how to inform the public about their sustainability-related achievements. At the same time, it is very important for hotel owners and managers to inform potential hotel guests about ongoing efforts and informing potential hotel guests is likely to affect their decision to choose a given hotel. It is likely also to affect the sustainability-related implementation decisions of competing hotels. However, according to A. NIEZGODA \& E. MARKIEWICZ (2015), greenwashing is the 'art' of turning ecology into popularity by some business entities that often use meaning-less catchphrases, describe the ecological properties of various products without any basis, and provide an image that does not match actual company behavior (NIEZGODA \& MARKIEWICZ 2015).

Political, legal, and economic mechanisms that may redirect the tourism sector towards attitudes that are more friendly to the natural environment (also applying to the hotel sector): industry-wide legal regulations 
such as international agreements, national laws, local laws, tourism sector rules, company initiatives, codes of ethics, and eco-certificates, and additional financial incentives, designation of new protected areas, assessments of impact on the environment, environmental management systems, sustainable development indicators, environmental reports, and visitor management systems (BOHDANOWICZ \& BOHDANOWICZ 2004).

It is important to note that the basis for a comprehensive approach to the implementation of the principles of sustainable development in tourism is the collaboration of entities interested in its development including hotel owners. However, collaboration is more of an exception than the rule. Collaboration is important in relation to business owners including suppliers of products and services to hotels, as well as in relation to other organizational entities. Local governments play a role in the establishment of tourismrelated businesses in a given geographic area. Earlier research has shown that local government officials rank their tourism-related collaboration with other local government officials highest. Collaboration with the academic community was ranked lowest, while collaboration with local business owners was ranked 'average' (KAPERA 2018). The question of sustainable development education remains open. In Poland the level of knowledge in this area remains insufficient, and sustainable development remains a niche subject of analysis for a relatively small group of research professionals (NIEZGODA 2004).

\section{FINAL REMARKS}

The hotel industry is increasingly taking responsibility for sustainable development in the natural environment and pursues pro-social efforts. However, the primary focus remains the protection of the resources of the natural environment. The industry's focus on energy usage, water usage, and garbage generation is directly linked with the financial benefits associated with the efficient functioning of hotels. The paper outlines a number of ways in which hotels implement sustainable development practices in their everyday operations. While these practices are not required by law and are not found at all hotels, the pattern of change is nevertheless positive. The implementation of the principles of sustainable development in hotel operations requires a comprehensive approach and intensified collaboration with partners engaged in the development of the tourism sector, and education at a number of levels of development. Research has shown that there exists a lack of legal regulations that would directly address tourism and that would force business owners to care to a greater extent for the natural environment, their employees, and local communities. A system of incentives is also needed in order to reward hotel guests who make an effort to support sustainable development. Applied research is needed in order to understand the motivations and behaviors of both employees and guests at hotels who choose to make an effort in the direction of sustainable development. It is necessary to conduct both qualitative and quantitative studies of hotel employee and hotel guest motivations and behaviors in order to help along the path to a more sustainable hotel industry.

\section{ENDNOTES}

1 The research on the development of sustainable tourism was carried out by the author and financed within the framework of the WPAiSM/DS/24/2018 project.

\section{BIBLIOGRAPHY}

BOHDANOWICZ J., BOHDANOWICZ P., Stymulatory ekonomiczne $i$ prawne polityki ekorozwoju dla turystyki, Konferencja pt. „Główne problemy badawcze i metodologiczne współczesnej politologii w Polsce", 8-10 listopada 2004, Władysławowo, Polska.

BORKOWSKA-NISZCZOTA M., 2015, Społeczna odpowiedzialność biznesu turystycznego na rzecz zrównoważonego rozwoju na przykładzie obiektów hotelarskich, Economics and Management, 1, pp. 368-392.

BRUNS-SMITH A., CHOY V., CHONG H., VERMA R., 2015, Environmental sustainability in the hospitality industry: Best practices, guest participation, and customer satisfaction, Cornell Hospitality Report, 15 (3), pp. 6-16.

BUTOWSKI L., 2013, Długookresowy model turystyki zrównoważonej, Zeszyty Naukowe Uczelni Vistula. Ekonomia, III, 32, pp. 5-28.

CITKOWSKI M. (ed.), 2010, Społeczna odpowiedzialność biznesu. Koncepcja i praktyka, Wydawnictwo Wyższej Szkoły Administracji Publicznej, Białystok.

DOMINIK P., 2017, Społeczna odpowiedzialność branży hotelarskiej i gastronomicznej, Przedsiębiorczość $i$ Zarządzanie, 18 2, II: Zarzadzanie humanistyczne i publiczne, Ł. Sułkowski, A.M. Migdał (eds.), pp. 265-278.

Ekspertyza dotycząca edukacji dla zrównoważonego rozwoju w Polsce. Raport końcowy, 2012, Zespół Konsultantów ITTI, Poznań, pp. 3-5.

FERMANI A., CRESPI I., STARA F., 2016, Sustainable hospitality and tourism at different ages: Women's and men's attitudes in Italy, Research in Hospitality Management, 6 (1), pp. 83-92

HENDEL M., 2016, Koncepcja konsumpcji zrównoważonej w turystyce jako możliwość realizacji założeń turystyki zrównoważonej, Marketing i Rynek, 2, pp. 13-19.

HENDEL M., ŻEMŁA M., 2016, Zrównoważona konsumpcja jako atrybut i uwarunkowanie rozwoju branży turystycznej w XXI wieku, Prace Komisji Geografii Przemystu Polskiego Towarzystwa Geograficznego, 30 (4), pp. 187-197.

ISO 26000: 2010, Guidance on social responsibility, 2010, ISO.

JONES P., HILLIER D., COMFORT D., 2016, Sustainability in the hospitality industry: Some personal reflections on corporate 
challenges and research agendas, International Journal of Contemporary Hospitality Management, 28 (1), pp. 36-67.

KAPERA I., 2018, Sustainable tourism development efforts by local governments in Poland, Sustainable Cities and Society, 40, pp. 581-588.

KAPERA I., WSZENDYBYŁ-SKULSKA E., 2017, Pro-ecological hotel policies as assessed by guest, Turyzm/Tourism, 27, 2, pp. 57-62.

KAZIMIERCZAK M., 2010, Jaką aksjologię zakłada idea zrównoważonego rozwoju w turystyce?, Turystyka i Rekreacja. Studia i Prace, 6: Uwarunkowania i plany rozwoju turystyki. Turystyka zrównoważona, Z. Młynarczyk, I. Potocka, A. Zajadacz (eds.), s. 9-18.

Konstytucja Rzeczypospolitej Polskiej z dnia 2 kwietnia 1997 roku, DzU 1997, nr 78, poz. 483.

KOWALCZYK A., (ed.), 2010 Turystyka zrównoważona, Wyd. Naukowe PWN, Warszawa.

KOWALCZYK A., 2010, Turystyka zrównoważona - aspekty kulturowe, Turystyka i Rekreacja. Studia i Prace, 6: Uwarunkowania i plany rozwoju turystyki. Turystyka zrównoważona, Z. Młynarczyk, I. Potocka, A. Zajadacz (eds.), pp. 19-29.

KRONENBERG J., 2011, Zrównoważony rozwój a powiązanie z miejscem i lokalną społecznością - Dwór w Tomaszowicach, Zrównoważony Rozwój - Zastosowania, 2, pp. 52-65.

Marketingowa strategia Polski w sektorze turystyki na lata 2012-2020, 2011, Warszawa.

MAZUR-WIERZBICKA E., 2018, Społeczna odpowiedzialność biznesu w branży hotelarskiej, Ekonomiczne Problemy Turystyki, 1 (41), pp. 59-66.

MELISSEN F., 2013, Sustainable hospitality: A meaningful notion?, Journal of Sustainable Tourism, 21, pp. 810-824.

MIKA M., 2015, Sustainable tourism, a critique of the academic feasibility of the concept, Turyzm/Tourism, 25, 1, pp. 9-17.

NieZGODA A., 2004, Problems of implementing sustainable tourism in Poland, Economics and Bussines Review, 1 (4), pp. 30-42.

NiEZGODA A., 2010, Ekologiczne uwarunkowania zachowań nabywczych w turystyce, Zeszyty Naukowe Uniwersytetu Szczecińskiego. Ekonomiczne Problemy Ustug, 52, pp. 643-652.
NIEZGODA A., MARKIEWICZ E., 2015, Turystyka biznesowa a turystyka zrównoważona - przykład hotelu $\mathrm{w}$ aglomeracji, Zeszyty Naukowe Wyższej Szkoły Bankowej w Poznaniu, 63 (6), pp. 226-240.

Pogranicze polsko-stowackie. Dostępność transportowa a turystyka, 2012, Instytut Geografii i Przestrzennego Zagospodarowania Polska Akademia Nauk, Geografický ústav Slovenská akadémia vied, Warszawa-Bratysława.

Polska Market Insights Raport Roczny, 2016, Colliers International, Warszawa.

PN-ISO 2600: 2012, Wytyczne dotyczace społecznej odpowiedzialności, 2012.

Program rozwoju turystyki do 2020 roku, 2015, Warszawa.

PRZYBYLSKA A., 2012, CSR jako narzędzie rozwoju i promocji przedsiębiorstw turystycznych, Zeszyty Naukowe Uniwersytetu Szczecińskiego. Ekonomiczne Problemy Ustug, 86, pp. 343-355.

RHEEDE VAN A., BLOMME R.J., 2012, Sustainable practices in hospitality: A research framework, Advances in Hospitality and Leisure, 8, J.S. Chen (ed.), Emerald Group Publishing Limited, pp. 257-271.

SALA J., 2009, Formy wspótczesnego hotelarstwa, WUE, Kraków.

SLOAN P., LEGRAND W., CHEN J. S., 2009, Sustainability in the hospitality industry: Principles of sustainable operations, Elsevier, Oxford.

Strategia na rzecz Odpowiedzialnego Rozwoju do roku 2020 (z perspektywą do 2030 r.), 2017, Warszawa.

SzTORC M., 2017, Problematyka zrównoważonego rozwoju oparta na wartościach w strategiach przedsiębiorstw hotelarskich, Studia i Materiaty. Miscellanea Oeconomicae, 2, pp. 303-316.

SZYMAŃSKA E., 2014, Zarządzanie usługami noclegowymi w świetle zasad zrównoważonej turystyki, Logistyka, 3, pp. 62016214.

Turystyka w 2017, 2018, GUS, Warszawa.

Ustawa z dnia 27 kwietnia 2001 r. Prawo ochrony środowiska, DzU 2001, nr 62, poz. 627, ze zm.

https://plgbc.org.pl/baza-budynkow-certyfikowanych/.

Article received:

8 October 2018

Accepted:

15 November 2018 